Jurnal Ilmu dan Teknologi Peternakan Indonesia Volume 4 (1) 238-247; Juli 2018

ISSN: 2460-6669

\title{
Diseases characteristic of pre-weaning Bali calf (Bos javanicus) in Central Lombok, Indonesia
}

\author{
AS Dradjat*, M Imran**, TS Panjaitan", Dahlanuddin** \\ *Animal Reproduction, ${ }^{* *}$ Animal Nutrition Mataram University, "Balai Penelitian Teknologi \\ Pertanian NTB.
}

Corresponding author ${ }^{(*)}$ Faculty of Animal Science University of Mataram, J1. Majapahit 62 Mataram 83125, Lombok, NTB, Indonesia. E mail: Adji.dradjat@yahoo.com. Telephone: 0370 633603. Fax: 0370640592

\begin{abstract}
The aim of the study was to evaluate Bali cattle pre-weaning calf death in Central Lombok. Sick calves were examined their condition, followed by physiology examination. Then feces and blood samples were collected and examined for internal parasites and hematology. The results showed that the newborn calf was $57,2 \%$ (61), while calves sick was $16.5 \%$ (101) consisted of $7,2 \%$ (57) death calves and 9,3\% still alive. Calves examination showed that $21,05 \%$ (12) was under weak conditions, 38.5\% (22) with high temperature, 73, 5\% (42) calves were found diarrhea. This diarrhea calves consisted of 50,8\% (29) diarrhea, 3, 5\% (2) diarrhea with blood stain, and 19,2\% (11) diarrhea with high temperature. The results of coproscopy showed that $14.03 \%$ (8) calves diarrhea were infected with parasites, such as protozoa (Eimeria sp), liver fluke (Fasciola sp) and gastro intestine worm (Trichuris sp, Trichostrongilus sp, and Bunostonum sp). Following evaluation of hematocrit, it was found that $33.3 \%$ (19) calves higher while $3.50 \%$ (2) lower. Following examination of Red Blood Cell, it was found that $98.2 \%$ (56) calves showed anemia hypochromic, $28.07 \%$ (16) showed anemia microcytic, 15,7\% (9) macrocytic anemia, 5.2\% (3) anemia hypochromic, 3.5\% (2 calves) showed erythropenia. Leucocytes examinations showed that $35.08 \%$ (20 calves) showed by lymphocytosis, $7.01 \%$ (4 calves) leucocytosis, $1.75 \%$ ( 1 calf) leucopenia and $1.75 \%$ ( 1 calf) lymphocytopenia. It can be concluded that from the ill calves in the middle of the rainy season showed diarrhea with protozoa, liver fluke, and worms infestations. Hematology examination the sick calves indicated that there were anemia, lymphocytosis, dehydration, low content of blood corpuscular. Finally, the sick calves may be infected with parasites, protozoa's, bacteria's and viruses.
\end{abstract}

Keywords: coproscopy, hematology, calf, Bali cattle.

\section{INTRODUCTION}

Mortality in the early live of cattle would be mayor economic losses (Singh et al, 2009; Ferede et al, 2014). These losses would be more significance in small holder farmers, as percentage of calf's death would be higher than that of large number producer. It was also reported that low productivity with body weight gain at $0.2 \mathrm{~kg} / \mathrm{day}$, may be resulted following recovery from disease. (Dahlanuddin et al 2012).

Calves death were reported can be caused by nutritional, environmental and management factors (Fordyce et al, 2014). Firstly nutrition factor, it was found that when feed was improved by feed supplementation, calves death could be reduced (Jelantik et al, 2009). Secondly management factor, it was reported that low 
levels of knowledge of farmers resulted in poor practice and may leads to higher calves mortality (Chang'a et al, 2010). Thirdly environment factor, it was reported that when environmental improvement such as by good hygiene and housing, calves mortality was decreased (Svensson et al, 2006; Moran, 2011), further more in different climate such as in rainy season calves mortality was higher than that of summer and winter (Yeasmin et al, 2014).

There are two season dry and wet in the tropic which may lead to calves mortality. Greater loss was reported related to hot and dry weather (Martin et al, 1975) and often as high as 50\% (Moran 2011). High calves mortality was also reported in beef cattle in tropical areas Australia up to 67\% (Bunter et al, 2012). In tropical areas during drought of dry season it was reported that calves mortality of Bali cattle in Indonesia was reported 30 to $52 \%$ (Wirdahayati et al, 2000). During rainy season in tropic would be wet and more humid/ more infection and diseases calves mortalities was reported up to $15 \%$ (Dahlanuddin et al 2012). Further information showed that calf morbidity higher in wet season than dry season $(65.3 \%$ vs. $55.7 \%$ ), however calf mortality higher in dry season than that of wet season was $33.0 \%$ in was $28.1 \%$ (Ferede et al, 2014). It was reported that calf death was higher in rainy season up to $42.8 \%$ than summer $(33.35 \%)$ and winter $(23.80 \%)$ (Yeasmin et al, 2014). It was reported that calf mortality mainly because of rain fall (Martin et al, 1975). Calf mortality of $12.6 \%$ caused by microbial and management (Yeasmin et al, 2014), this condition were potential for infection and consequently there are significant number of calves getting sick and deaths. Calf death of small holder dairy farm in Tanzania was reported $20 \%$ (Chang'a et al 2010).
Hence it would valuable to evaluate the evident of calves death and diseases during the rainy season of back yard farming. The aims of the study were to examine the state of physiology unhealthy pre-weaning calves which were evaluated by external examination, laboratory evaluation of fesses for parasites and blood for hematology can be used as a tool bovine medicine (Roland et al 2014). It was expected that by identification of disease, would provide information to prevent excessive death during rainy season.

\section{MATERIALS AND METHODS}

\section{Research areas}

This research was performed in Central Lombok Island of Indonesia, as warm, humid tropical areas, with two seasons. Rainy season starts from October to April, with rainfall 92-216 $\mathrm{mm}$, 9-17 rainy days per month, while dry season begins from May to September with rainfall 4-60 mm and 0-7 rainy days per month. As a warm and humid area, Lombok Island has average temperature between $26-28^{\circ} \mathrm{C}, 22-24^{\circ} \mathrm{C}$ at night and $30-32^{\circ} \mathrm{C}$ with humidity up to $80 \%$. This island is agriculture areas with rice as main production; most of the area is rice fields with irrigation throughout the year. Raising cattle traditionally is part of activities of rice producer in Lombok Island of Indonesia.

\section{Cattle management}

Farmers in Lombok raise cattle as backyard farming, in a small number, however for security reasons, farmer raised cattle in one area call group. In Group of farmer, cattle were collected and rise in cattle housing, feed and management was done by individual farmers. There were 36 groups of farmers, each group consist between 10 and 20 farmers and raise cattle between 18 and 66 cattle involved in this study. Cattle were 
fed by cutting and carrying grass from rice field areas.

\section{Samples collection}

Samples collected for this study were firstly data of sick calves were collected from group. Then calves were examined by 1 . Conditions of calves, such as good, medium and low condition. 2. Then physically or physiologically such as respiratory, heart rate and rectal temperature. 3. The calves were examined whether any indication of diarrhea such as diarrhea with high temperature rectal, with blood stain or just only diarrhea. 4. Fecal samples collected from rectum to examine worm's eggs by coproscopy 5. Blood samples collected from jugular's vein for hematology examination.

\section{Physical and external examination}

Physical examination was performed include rectal temperature, heart bits and respiratory rates. Examination of rectal temperature was performed swinging thermometer when it showed $35^{\circ} \mathrm{C}$ then inserted into rectum and ready to read when it was in the rectum for 5 minutes. Examination of heart rate was performed by using stethoscope at the axial of left front leg by counting systolic sound for one minute. Respiratory examination was performed by put right hand in front of calve noses, expiration was count for one minutes it can be feel by hand. Calves normal temperature, heart rate and respiratory rate were $38^{\circ} \mathrm{C}-39,5^{\circ} \mathrm{C}$, and 100 140 per minute and 24-26 per minute. Examination of diarrhea was performed by examining feces consistency with categories normal, diarrhea and diarrhea with blood stain.

\section{Fecal collection and examination}

Feces collection was performed by covering hand using glove inserted finger into anus until get approximately more than 5 gram feces. Examination coproscopy consist of two techniques those are for Nematodes and Trematodes.

Examination of eggs per gram feces for nematodes was performed by 1 gram feces added $10 \mathrm{ml}$ water, grinded (digerus) and filtered for, homogenous part centrifuges $1000 \mathrm{rpm} / 10$ minutes. Then pour the supernatant and the filtrate added with sugar saturated aquadest up to $1 / 3$ tube and stirred. Saturated sugar was filled up to $90 \%$ of the tube, followed by centrifuge $1000 \mathrm{rpm}$ for 10 minutes, placed vertically, drop saturated sugar until the surface of the tube. At the top surface of the put cover glass for 20 minute, and then put the cover glass on the object glass and examined under microscope. Identify worm eggs by shapes, structure and size then compare to the literature.

Trematodes examination was performed by weighing 3 gram feces added to $50 \mathrm{ml}$ aquadest and stirred nicely, keep steady for 5 minutes, pour the supernatant and the filtrate added with $10 \mathrm{ml}$ aquadest and keep still for 5 minutes and pour it, left $5 \mathrm{ml}$ filtrate. Then drop the filtrate with a drop of methylene blue, stirred and drop in the object glass and examined under microscope. Fasciola sp eggs can be identified when it shows yellow color while Paramphistomas eggs (rumen trematodes) shows bluish color.

\section{Blood samples collection and hematology examination}

Hematology examination was performed using whole blood collected from jugularis vein of the calves and dispensed into a $10 \mathrm{ml}$ vacum tube contain ethylene diamine tetra acetic acid (EDTA). White blood cells (WBC) were measured by Cell Count Method for neutrophil), lymphocyte and monocyte. Red blood cells count (RBC), concentration of haemoglobin (HGB), and thrombocytes (PLT) were also measured. All hematology examination was performed 
by automatic hematology machine SYSMEX KX-21...

The results of research showed that from 36

\section{Data and statistic analysis}

Data were analyzed using description as number and percentage (\%) as comparison hematology standard (George et al, 2010) was used. groups of farmers totally raised 2161 cattle consist of 1068 cows, with 611 new born calves or $57,2 \%$ from total cows, $57(9,3 \%)$ calves was ill during the middle of rainy season and calves mortality 44 heads $(7,2 \%)$ from the new born calves (Table 1).

\section{RESULTS}

Table 1. Description of cattle raised in groups participated in the research.

\begin{tabular}{llll}
\hline No & Description & Number & Notes \\
\hline 1 & Farmers (group) & 36 & In Central Lombok Island \\
2 & Bulls (head) & 108 & For fattening and matting \\
3 & Cows (head) & 1068 & Have been deliver calf \\
& Calves (head) & 611 & Born in that year \\
4 & Calving rate (\%) & 57.20 & Born in that year \\
5 & Weaned calves (head) & 449 & $6-12$ months old \\
6 & Pre weaning calves (head) & 162 & Less than 6 month old \\
7 & Pre weaning calves sick (head) & 101 & Reported for medication \\
8 & Pre weaning calves sick and die (head/ \%) & $44(7.2 \%)$ & Reported by farmers \\
9 & Pre weaning calves still sick (head/\%) & $57(9.3 \%)$ & To be used in this study \\
\hline
\end{tabular}

During middle of rainy season, following examination of calves conditions from 57

calves which have been indicated being low appetite (Table 2).

Table 2. Condition of sick calves the mid of rainy season.

\begin{tabular}{llll}
\hline No & Descriptions & Head & \% \\
\hline 1 & Standing alert & none & None \\
\hline 2 & Standing, depressed, slight dehydration & 45 & 78,94 \\
\hline 3 & Sternal, depressed, moderate dehydration & 12 & 21,05 \\
\hline & Total calves ill & 57 & 100 \\
\hline
\end{tabular}

Physiological examination of the sick calves with low appetite, weak and diarrhea which have been suffered for between 3 day and 2 weeks showed in Table 3.

Table 3. Results of physiological examination of calves.

\begin{tabular}{llll}
\hline No & Physiological examination & Heads & Percentage (\%) \\
\hline 1 & High respiratory rates & 3 & 5,2 \\
2 & High heart rates & 4 & 7,0 \\
3 & High rectal temperature & 22 & 38,5 \\
\hline
\end{tabular}

External physical examination results such as diarrhea, bloody diarrhea, diarrhea and rectal temperature presented in Table 4.

Table 4. Results of examination of 57 calves in the middle of rainy season. 
Jurnal Ilmu dan Teknologi Peternakan Indonesia Volume 4 (1) 238-247; Juli 2018

ISSN: 2460-6669

\begin{tabular}{llll}
\hline No & Examination results & Number (heads) & Percentage (\%) \\
\hline 1 & Diarrhea & 29 & 50,87 \\
\hline 2 & Diarrhea with temperature $>39,5^{\circ} \mathrm{C}$ & 11 & 19,29 \\
3 & Diarrhea with blood stain & 2 & 3,50 \\
\cline { 2 - 4 } & Total calves diarrhea & 42 & 73.69 \\
4 & No indication of diarrhea & 15 & 26,31 \\
\hline & Total calves sick & 57 & 100 \\
\hline
\end{tabular}

Egg identification showed in Table 5. that infestation Ascaris sp in 9 calves, Fasciola

Trichuris sp in 2 calves, Trichostrongilus sp in 1 calf and Bunostonum sp in 1 calf. $s p$ in 2 calves, Eimeria $s p$ in 2 calves, Table 5. Identification of parasites infested to the calves from 57 calves reported by farmers.

\begin{tabular}{lll}
\hline No & Parasites detected by coproscopy (+ epg) & No / \% \\
\hline 1 & Ascaris & 6 \\
2 & Ascaris, Eimeria & 1 \\
3 & Ascaris, Bunostonum & 1 \\
4 & Ascaris, Eimeria, Fasciola sp & 1 \\
5 & Fasciola sp & 1 \\
6 & Trichuris & 1 \\
12 & Trichuris, Trichostrongilus & 1 \\
\hline
\end{tabular}

By referring to hematology standard of George et al, (2010) the hematology RBC and WBC, solid part of blood can be categorized into low and high levels of hematocrit. Low levels of hemoglobin, Low

Table 7. Results of categorize of hematology by comparison with reference of normal range (George et al, 2010).

\begin{tabular}{llll}
\hline Hematology & Categories & Calves $(\%)$ & Normal* \\
\hline Hematocrit $(\%)$ & More than 33 & $19(33.33)$ & $22-33$ \\
Hematocrit $(\%)$ & Less than 22 & $2(3.50)$ & $22-33$ \\
Hemoglobin $(\mathrm{g} / \mathrm{dl})$ & Less than 8.5 & $3(5.26)$ & $8.5-12.2$ \\
Erythrocytes $\left(10^{6} / \mu 1\right)$ & Less than 5.1 & $2(3.50)$ & $5.1-7.6$ \\
Lymphocytosis $\left(10^{3} / \mu \mathrm{l}\right)$ & More than 5.6 & $20(35.8)$ & $1.6-5.6$ \\
Leukocytosis $\left(10^{3} / \mu \mathrm{l}\right)$ & More than 12 & $4(7.01)$ & $4.9-12.0$ \\
Leucopenia $\left(10^{3} / \mu 1\right)$ & Less than 4.9 & $1(1.75)$ & $4.9-12.0$ \\
Lymphocytopenia $\left(10^{3} / \mu \mathrm{l}\right)$ & Less than 1.6 & $1(1.75)$ & $1.6-5.6$ \\
\hline
\end{tabular}

*George et al, 2010

\section{DISCUSSIONS}

The results (Table 1) showed that calves born in farmers group in central Lombok Island was $57.2 \%$ from the total cows which involve in this study. This calving rate was levels of erythrocytes. Evaluation of WBC consists of Lymphocytosis, Leucocytosis, Leucopenia and Lymphocytopenia (Table7). 
mating management can be applied by providing bull with mating schedule.

The results of research showed that calves morbidity and mortality were $9.3 \%$ and $7.2 \%$ respectively, from the number of calves delivered in that year (Table 1). In comparison with Swedish dairy herds, Bali cattle have lower morbidity and higher mortality, it was reported in Swedish dairy herds that calves morbidity and mortality were $11.0 \%$ and $2.6 \%$ respectively (Olsson et al 1993). Others report showed that calves mortality was relatively low up to $4.6 \%$. (Gulliksen et al 2009) found that calf mortality varied between $4 \%$ and $32 \%$ (Perry et al 1984). This wide variation may be because of various on management diseases, preventions and medications (Bendali et al 1999; Ortiz-Pelaeza et al 2008).

During examination of calves, it was found (Table 2) that $21.05 \%$ of calves was under weak conditions and (Table 3 ) showed that $6.52 \%$ had high respiratory rates, 8 , and $69 \%$ had high heart rates and $47.82 \%$ had high rectal temperature. It was reported that bacteria of Escherichia coli was isolated of $20.3 \%$ of calves on the first day following calving (Bendali et al 1999) and diseases caused calves mortality were parasites infestations, protozoa's, bacteria's and viruses infection (Faries 2010) with signs of diarrhea $43 \%$ (Virtala et al 1996), pneumonia $16.8 \%$ (Mulei 1995) and 24\% (Virtala et al 1996), septicemia 10\% (Virtala et al 1996). Other cases of calves mortalities were musculoskeletal diseases (7.0\%), septicemia (6.7\%), malnutrition (6.1\%), cardiovascular system (3.7\%), nervous system $(3.2 \%)$, liver $(2.6 \%)$ and poisoning (2.6\%) (Mulei 1995).

Table 3, 38.5\% had high rectal temperature. It is known that body temperature increase higher than normal because of bacterial infections. When body temperature higher than normal it may be indicated of bacterial infection (Roland et al 2014),

Following examination of calves (Table 4), it was found that diarrhea with blood stain was $3.50 \%$, diarrhea with rectal temperature higher than $39.5^{\circ} \mathrm{C}$ was $19.29 \%$, diarrhea was found $50.87 \%$ and no sign of diarrhea was $26.31 \%$. The other research results showed that $52 \%$ diarrhea was detected at first week $15 \%$ was detected at second week after calving (Bendali et al 1999). Enteritis was lead calves mortality up to $44 \%$ (Sivulaa et al 1996). It was reported that there was no effect of season to diarrhea, however change of feed and management may stimulates intestine microbes to develop becomes pathogen (Curtis et al 1988).

The results of research show that examination of coproscopy (Table 5) showed infestation of Fasciola sp, Eimeria $s p$, Trichuris sp, Trichostrongilus $s p$ and Bunostonum sp. Previous research showed that disturbance of gastro intestine usually detected in calves 1-30 days of age (Mulei 1995). Calves death of gastroenteritis, $31.3 \%$ caused by colibacillosis, salmonellosis, coccidiosis, helminthiasis, and bload (Mulei 1995). It was reported that protozoa such as cryptosporidia, coccidia has been isolated (Faries 2010) with signs of diarrhea with blood stain.

Hematocrit evaluates percentage solid part of the whole blood; the sick calves may show high or low percentage of hematocrit. In this study it was found that a high level of hematocrit which is more than $33 \%$ was found in 19 calves or $33.33 \%$. It seems that 19 calves indicate that they suffer of dehydration or blood loss. On the other hand there was low hematocrit when solid parts of blood less than $22 \%$. It was found in 2 calves or this $3.50 \%$ of calves may suffer of protein deficiency and low corpuscular content of blood and hence, resulted in low hematocrit. It was reported that calves 
mortality on the age of 14 weeks, showed low blood hematocrit (Donovan et al 1986). It was found that by referring hematological standard of George et al (2010) there are categories of hematological examination varied widely lower and higher than the normal conditions (Table 6 and 7). The most common cause of calves sick can be categorized as suffer of anemia, it was shown by: Firstly, evaluation of low MCHC it was found in 56 calves or $98.24 \%$ indicated that the calves suffer of anemia hipochromic of corpuscular erythrocytes. Secondly, evaluation of low $\mathrm{MCH}$, it was found in 16 calves or $28.07 \%$ indicates that the size erythrocytes in blood circulation relatively small called microcytic anemia. Thirdly, higher MCV was found in 9 calves or $15.78 \%$, indicated that the erythrocytes in blood circulation was in large size which called as macrocytic erythrocytes. Fourthly, low levels of hemoglobin concentration, it was found in 3 calves or $5.26 \%$ indicated that the calves suffer of anemia called hypochromic erythrocytes. Fifth, low levels of erythrocytes, it was found in 2 calves or $3.50 \%$, it is indicated that the calves suffer anemia by low number of erythrocytes. Under normal condition erythrocyte and hemoglobin can be classified as normocytic or normal size cells and normochromic or normal color. Under anemia conditions erythrocyte may show microcytic hypochromic or macrocytic hypochromic. Leucositosis and leucopenia were found in the study, leukocytosis was found in 4 or $7.01 \%$ of calves while leukopenia was found in 1 calf or $1,75 \%$. Single WBC parameter alone is difficult to be used as definite diagnostic tools without other hematologic parameters (Roland et al 2016). Hence, other hemogram information was required to confirm WBC as diagnostic tools.

Lymphocytosis is when more than $5.6 \times 10^{3} / \mu 1$ lymphocytes were found in 20 calves or $35.08 \%$ of calves, it is indicated that there is infection occurring. Increasing of lymphocyte concentrations may show healing phase of infectious virus disease, chronic antigen stimulation (Roland et al 2014). When lymphocyte increases, this may be because of viral infection (Xu et al 1993; Faries 2010) or may be response of cancer diseases (Ferrer et al 1978). Lymphocytopenia is when less than $1.6 \times 10^{3} / \mu 1$ lymphocytes were found in 1 calves or $1.75 \%$ of calves indicated on the blood circulation have less lymphocytes. Lymphocytopenia can be causes by viral or bacterial infection, immune suppression, chronic renal insufficiency (Roland et al 2014).

During the rainy season it shows that wet and watery areas increase the risk of infection which may lead to diarrhea and pneumonia (Agerholm et al 1993; Lundborg et al 2005) of calves. Hygiene the surrounding and daily management is a risk factor to diarrhea, respiratory diseases, bacterial and virus infections (Lundborg et al 2005). Infection of Escherichia coli leads calves mortality $50.9 \%$ to $74.6 \%$ from total death calves (House 1978). Studies showed that Rotavirus has been isolated from $47.4 \%$ (Bendali et al 1999), Corona virus from 16.5 $\%$ samples (Bendali et al 1999) which related to calves diarrhea.

\section{CONCLUSIONS}

It can be concluded that mortality preweaning calves was 7,2\% (44 heads) and $1,9 \%$ (12 heads) sick under weak conditions with diarrhea, diarrhea with blood stain and diarrhea with rectal temperature higher than $39.5^{\circ} \mathrm{C}$. Following coproscopy it was identified that the sick calves were invested with protozoa (Eimeria $s p$ ), liver fluke (Fasciola sp) and gastro intestine worm (Trichuris sp, Trichostrongilus sp and Bunostonum sp). Following hematology RBC examination it was found that anemia hypochromic $98.24 \%$, anemia microcytic $28.07 \%$, anemia macrocytic, $15.78 \%$, 
hyphocromic anemia $5.26 \%$, erythropenia $3.50 \%$, dehydration, 33.33\%, low corpuscular content $3.50 \%$ from sick calves. Hematology study of WBC, it was found that lymphocytosis $35.08 \%$, leukocytosis $7.01 \%$, leukopenia $1.75 \%$, lymphocytopenia $1.75 \%$ from the number of sick calves. Following hematology evaluation related rectal temperature higher than $39^{\circ} \mathrm{C}$ showed lymphocytosis. It shows that the sick calves probably not only because of parasites and bacteria's but also may be infected by viruses. It is indicated low levels of knowledge of farmers and poor calf management; it showed that intervention from local husbandry office to improve knowledge and medication.

\section{ACKNOWLEDGEMENT}

This research was funded partly by the Australian Centre for International Agricultural Research (ACIAR). The authors acknowledge to Murama Hasyura and Syahrul Zubaidi for collecting samples. The authors also thanks to Dr Muhammad Imran due to organizing groups of farmer to ease calves examination and samples collection.

\section{REFERENCES}

Agerholm J S, Basse A, Krogh H V, Christensen K, Rønsholt L 1993 Abortion and calf mortality in Danish cattle herds. Acta Vet Scand. 34(4):371377.

https://medicalresearchjournal.org/inde x.php/GJMR/.../149

Amuamuta A, Asseged B, Goshu G. 2006. Mortality analysis of Fogera calves and their Friesian crossesin Andassa cattle breeding and improvement ranch, Northwestern Ethiopia. Revue Med. Vet. 157,11:525-529
Bendali F, Bichet H, Schelcher F. and Sanaa M. 1999. Pattern of diarrhoea in newborn beef calves in south-west France. Veterinary Research. 30: 61-74. https://www.ncbi.nlm.nih.gov/pubmed/ 10081113

Curtis C R, Erb H N and White M E. 1988. Descriptive epidemiology of calfhood morbidity and mortality in New York holstein herds. Preventive Veterinary Medicine. 5 (4): 293-307. www.sciencedirect.com/science/article/ pii/.../pdf?md5...

Dahlanuddin, L A Zaenuri, Y A Sutaryono, Hermansyah, K Puspadi, C Mc Donald, L J Williams, J P Corfield and $\mathrm{M}$ van Wensveen. 2016. Scaling out integrated village management systems to improve Bali cattle productivity under small scale production systems in Lombik, Indonesia. Livestock Rural Researh Development.

Http://www.lrrd.org/lrrd28/5dahl28079. $\underline{\mathrm{htm}}$

Dahlanuddin, Yulianto TB, Priyanti A, Poppy DP and Quigly SP 2012 Weaning and supplementationincrease liveweight gain of Bali (Bos javanicus) cattle of small holder farmers in Central Lombok, Indonesia. Animal Production 14(3):173-179.

www.researchgate.net/profile/Dahlanud $\underline{\operatorname{din}}$

Donovan G A, Badinga L, Collier R J, Wilcox C J and Braun R K, 1986. Factors Influencing Passive Transfer in Dairy Calves. Journal of Dairy Science. 69 (3):754-759.

https://www.ncbi.nlm.nih.gov/pubmed/ 3711407

Ersbøll A K, Rugbjerg $\mathrm{H}$ and Stryhn H. 2003. Increased Mortality Among Calves in Danish Cattle Herds During Bovine Virus Diarrhoea Infection, 11th International Conference on Production Diseases in Farm Animals. Acta 
Veterinaria Scandinavica. 44 (Suppl $1): 49$.

https://actavetscand.biomedcentral.com/ .../1751-0147-44-S1...

Ferede Y, Mazengia H, Bimrev T, Bitew A. 2014. Pre-weaning morbidity and mortality of crossbred calves in Bahir Dar Zuria and Gozamen Districts of Amhara region, Northwest Ethiopia. Open Access Library Journal, 1:e600. http://dx.doi.org/10.4236/oalib.1100600

Ferrer J F, Marshak R R, Abt D A and Kenyon S J. 1978. Persistent lymphocytosis in cattle: Its cause,nature and relation to lymphosarcoma. Ann RechVe. 9(4):851-857. https://hal.inria.fr/docs/00/90/10/79/.../h al-00901079.pdf

Fordyce G, Mc Gowan M, Mc Cosker K and Burns B. (2014). Reproductive wastage in extensively-managed beef cattle. In: David S. Beggs, Proceedings of the XXVIII World Buiatrics Congress: Abstracts. WBC 2014: XXVIII World Buiatrics Congress, Cairns, QLD, Australia, (). 27 July-1 August, 2014.https://espace.library.uq.edu.au/vi ew/UQ:354964

George J W, Snipes J and Lane V M. 2010. Comparison of bovine hematology reference intervals from 1957-2006. Vet Clin Pathol 39:138-148

Gulliksen S M, Lie K I, Løken T, Østerås O. 2009. Calf mortality in Norwegian dairy herds. Journal of Dairy Science. 92 (6): 2782-2795.

https://www.ncbi.nlm.nih.gov/pubmed/ $\underline{19448012}$

Hossain MM, Islam MS, Kamal AHM, Rahman AKMA and Cho HS. 2014. Dairy cattle mortality in an organized herd in Bangladesh. Veterinary World. 7(5):331-336. http://creativecommons.org/licences/by/ $\underline{2.0}$
House J A. 1978. Economic impact of rotavirus and other neonatal disease agents of animals. Journal American Veterinary Medicine Association. 173:573-576.

https://www.ncbi.nlm.nih.gov/pmc/artic les/PMC149593/

Jelantik, I G. N. 2001. Improving Bali cattle (Bibos banteng Wagner) Production Through Protein Supplementation. Ph.D Thesis. Dept. Anim. Sci. And Anim. Health. The Royal Veterinary and Agricultural University, Denmark.

Lundborg G K, Svensson E C and Oltenacu P A. 2005. Herd-level risk factors for infectious diseases in Swedish dairy calves aged 0-90 days Preventive Veterinary Medicine, 68 (2-4):123-143. www.academia.edu/.../Herdlevel_risk_factors_for_infectiou..

Martin SW, Schwabe CW, Franti CE. 1975. Dairy calf mortality rate: influence of meteorologic factors on calf mortality rate in Tulare County, California. Am J Vet Res. 1975 Aug;36(08):1105-9.

Mulei C M, Gitau G K, and Mbuthia P G. 1995. Causes of calf mortality in Kabete area of Kenya. Onderstepoort Journal Veterinary Research. 62(3):181-185.

https://www.ncbi.nlm.nih.gov/pubmed/ $\underline{8628571}$

Olsson S O, Viring S, Emanuelsson U, and Jacobsson S O. 1993. Calf diseases and mortality in Swedish dairy herds. Acta Vet Scand. 34(3):263-269. https://www.ncbi.nlm.nih.gov/pubmed/ $\underline{8310899}$

Ortiz-Pelaeza A, Pritchard D G, Pfeiffer D U, Jones E, Honeyman P and Mawdsley J J. 2008. Calf mortality as a welfare indicator on British cattle farms. The Veterinary Journal, 176 (2):177-181. https://www.ncbi.nlm.nih.gov/pubmed/ $\underline{17408994}$ 
Perry B D, Mwanaumo B, Schels H F, Eicher E and Zaman M R. 1984. A study of health and productivity of traditionally managed cattle in Zambia Preventive Veterinary Medicine. 2 (5):633-653.

https://www.ncbi.nlm.nih.gov/pubmed/ 17408994

Roland L, Drillich M, Iwersen M. 2014. Hematology as a diagnostic tool in bovine medicine. Journal of Veterinary Diagnostic Investigation. 26(5)592-598. https://www.ncbi.nlm.nih.gov/pubmed/ $\underline{25121728}$

Singh DD, Kumar M, Choudhary and Singh HN. 2009. Neonatal calf mortality. Intas Polivet. 10(II): 165-169.

Sivula N J, Ames T R, Marsh W E and Werdin R E. 1996. Descriptive epidemiology of morbidity and mortality in Minnesota dairy heifer calves Preventive Veterinary Medicine. 27(3-4):155-171.

https://www.infona.pl/.../bwmeta1.elem ent.elsevier-d6d5491

Svensson C, Linder A, Olsson SO. 2006. Mortality in Swedish dairy calves and replacement heifers.J Dairy Sci. 2006 Dec;89(12):4769-77.

https://www.ncbi.nlm.nih.gov/pubmed/ 17106108

Virtala A M K, Mechor G D, Gröhn Y T, Erb H N. 1996. The Effect of Calfhood Diseases on Growth of Female Dairy Calves During the First 3 Months of Life in New York State. Journal of Dairy Science.79 (6):1040-1049. https://www.ncbi.nlm.nih.gov/pubmed/ $\underline{8827469}$

Walz P H, Bell T G, Groom D L, Kaiser L, Maes R K and Backer J C. 2001. Platelet aggregation responses and virus isolation from platelet in calves experimentallyin infected with type I or type II bovine viral diarrhea virus. Canadian Journal of Veterinary $\begin{array}{lll}\text { Research } & 65 & \text { (4):241-247. }\end{array}$ https://www.ncbi.nlm.nih.gov/pmc/artic les/PMC1189686/

Wirdahayati RB, Fernadez PTh, Liem C and Bamualim A. 2000.Performance and Survival Rates of Beef Calves Inder Dry Tropic Condition of West Nusa Tenggara, Indonesia. Asian-Aus. J. Anim Sci. 13 Supl.2000B:196-108. www.asap.asn.au/livestocklibrary/.../Wi rdahayati 0392.pdf

$\mathrm{Xu} \mathrm{A}$, van Eijk M J, Park $\mathrm{C}$ and Lewin $\mathrm{H}$ A.1993. Polymorphism in BoLA-DRB3 exon 2 correlates with resistance to persistent lymphocytosis caused by bovine leukemia virus. The Journal of Immunology 151(2):6977-6985. www.jimmunol.org/content/151/12/697 $\underline{7}$

Yeasmin N, MK, Roy AC, Alam MS. 2014. Factors Affecting Calf Mortality in Small Scale Dairy Farms at Biswanath Upazilla of Sylhet. 2014. https://www.researchgate.net/scientificcontributions/2061936146_Nelufer_Ye $\underline{\text { asmin }}$ 